\title{
Dakwah Pemberdayaan Partisipasi Keluarga
}

\author{
Sugandi Miharja ${ }^{*}$, Syamsuddin RS. \\ ${ }^{1}$ Fakultas Dakwah dan Komunkasi, UIN Sunan Gunung Djati Bandung \\ *Email:miharja.uin@gmail.com
}

\begin{abstract}
This paper aims to describe the dynamics of family empowerment in supporting da'wah programs in the countryside. Changes to the order of life, including in the rural areas, need adaptation from the da'wah movement that can balance and fill the changes towards a more qualified society. The family is the smallest group component, at most, and is most directly related to da'wah activities in the countryside. Family participation as a subject and missionary partner will determine the overall success. The research method used is a qualitative approach with community empowerment interventions. The target community is religious leaders and the community of the da'wah congregation, including: DKM chairmen, the reciters of recitation, and the asatid\%, worshipers of mothers and teenagers as well as children of pengajian worshipers. Data obtained in the form of social and religious activities that have taken place in the village of Mandalasari. First, Social and Religious Activities. Second, Da'wah activities based on Empowering Family Participation. Third, the Role and Obligations as Family Members in empowering da'wah. Writing can describe a case about empowering da'wah through family participation in the countryside.
\end{abstract}

Keywords: Da'wab; Empowerment; Family Participation.

\begin{abstract}
ABSTRAK
Tulisan ini bertujuan untuk menggambarkan dinamika pemberdayaan keluarga dalam mendukung program dakwah di pedesaan. Perubahan pada tatanan kehidupan termasuk di pedesaan perlu adaftasi dari gerakan dakwah yang bisa mengimbangi dan mengisi perubahan menuju masyarakat yang lebih berkualitas. Keluarga merupakan komponen kelompok terkecil, paling banyak, dan paling berhubungan langsung dengan kegiatan dakwah di pedesaan. Peran serta keluarga sebagai subjek dan mitra dakwah menjadi sangat menentukan akan keberhasilan secara keseluruhan. Metode penelitian yang digunakan adalah pendekatan kualitatif dengan intervensi pemberdayaan masyarakat. Masyarakat sasaran adalah tokoh-tokoh keagamaan dan masyarakat jamaah dakwah, meliputi: Para ketua DKM, Ibu-ibu penggerak pengajian, dan para asatidz, para jamaah Ibu-ibu dan remaja serta anak-anak jamaah pengajian. Data yang diperoleh berupa keegiatan sosial dan keagamaan yang telah berlangsung di Desa Mandalasari. Pertama, Kegiatan Sosial dan Keagamaan. Kedua, Kegiatan Dakwah berbasis Pemberdayaan Partisipasi Keluarga. Ketiga, Peran dan Kewajiban sebagai Anggota Keluarga dalam dakwah pemberdayaan. Tulisan dapat menggambarkan suatu kasus tentang dakwah pemberdayaan melalui partisipasi keluarga di pedesaan.
\end{abstract}

Kata kunci : Dakwah; Pemberdayaan; Partisipasi Keluarga. 


\section{PENDAHULUAN}

Dalam konteks dakwah, pemberdayan keluarga memberikan sumbangsih yang tidak sedikit. Dengan keluarga yang berdaya, proses dan hasil dakwah diharapkan menjadi lebih produktif. Usaha dakwah berupa segala upaya dan kegiatan yang berencana mengandung ajakan dan seruan baik langsung atau tidak langsung, ditujukan kepada orang perorangan, masyarakat atau kelompok masyarakat agar tergugah jiwanya, terketuk hatinya ketika mendengarkan peringatan ajaran Islam. Seruan dakwah ini kemudian dapat dihayati, ditelaah dan dipelajari untuk diamalkan dalam kehidupan sehari-hari. Harapan hasil dakwah yang madani, lebih optimis dicapai manakala para keluarga dapat mendukung dan menjadi pengamal dakwah.

Berdasarkan kajian konsep dasar pemberdayaan keluarga untuk mendukung dakwah ini, terdapat harapan-harapan lebih. Pertama, orientasi pada kesejahteraan lahir dan batin masyarakat luas. Dakwah tidak dilaksanakan sekedar merumuskan keinginan sebagian masyarakat saja, tetapi direncanakan sebagai usaha membenahi kehidupan sosial bersama masyarakat agar penindasan, ketidakadilan dan kesewenangan tidak lagi hidup ditengah-tengah masyarakat. Skala makro yang menjadi sasaran dakwah bukan berarti meninggalkan skala mikro kepentingan individu anggota masyarakat. Kedua, dakwah pada dasarnya adalah ikhtiar melakukan social engineering (rekayasa sosial) untuk mendapatkan suatu perubahan tatanan kehidupan sosial yang terbaik.

Mengacu pada Moh. Ali Aziz (2004: 15-88), terdapat beberapa prinsip yang harus terpenuhi dalam dakwah yang didukung pemberdayaan keluarga, yaitu: pertama, prinsip Kebutuhan: program dakwah didasarkan atas dan untuk memenuhi kebutuhan masyarakat, baik materil dan non materil; kedua, prinsip partisipasi, menekankan keterlibatan masyarakat secara aktif dalam proses dakwah, mulai perencanaan, pengorganisasian, penggerakan, penilaian, dan pengembangannya; ketiga, prinsip keterpaduan, memadukan seluruh potensi dan sumber daya yang dimiliki oleh masyarakat, bukan monopoli sekelompok orang dan ahli, atau organisasi; keempat, prinsip berkelanjutanbahwa dakwah itu harus sustainable tidak dibatasi oleh waktu; keempatprinsip keserasian, antara kebutuhan jasmaniah dan ruhaniah masyarakat; kelima, prinsip kemampuan sendiri yang menegaskan bahwa kegiatan dakwah pengembangan masyarakat disusun dan dilaksanakan berdasarkan kemampuan dan sumbersumber (potensi) yang dimiliki masyarakat. Adapun keterlibatan pihak lain hanyalah bersifat sementara yang berfungsi sebagai fasilitator dan transformasi nilai keagamaan; keenam, dakwah tidak hanya dibatasi ceramah atau khutbah (dakwah bil-lisan), namun juga terdapat kegiatan nyata yang dapat mengangkat, meningkatkan harkat dan martabat kehidupan masyarakat (dakwah bil-hal). Karena dakwah dengan menggunakan metode ceramah saja kurang mengena dan kurang 
mendapat perhatian bila tidak dibarengi dengan aksi nyata yang membuahkan hasil berupa peningkatan kesejahteraan masyarakat.

Dengan uraian ini, upaya pemberdayaan keluarga pada dakwah adalah bagaimana sebenarnya keluarga mampu menjadi subjek aktif dari sukses dakwah, sehingga harapan perbaikan terjadi di semua sektor religi, sosial, budaya, maupun ekonomi. Hal ini sebagaimana disinyalir dalam al -qur'an surat ArRa'du:13, yang artinya: "Bagi manusia ada malaikat-malaikat yang selalu mengikutinya bergiliran, di muka dan di belakangnya, mereka menjaganya atas perintah Allah. Sesunggubnya Allah tidak merobah keadaan sesuatu kaum sehingga mereka merubah keadaan yang ada pada diri mereka sendiri.dan apabila Allab menghendaki keburukan terhadap sesuatu kaum, Maka tak ada yang dapat menolaknya; dan sekali-kali tak ada pelindung bagi mereka selain Dia (al Qur'an dan Terjemahnya, 2013).

Dari sisi budaya keagamaan di pedesaan terdapat beberapa amalan-amalan yang rutin dilakukan aik tiap hari, minggu maupun tiap bulan, dan tahun. Kebudayaan masyarakat yang ada sejak zaman dulu di antaranya: tradisi ngaruat lembur, tradisi ziarah, tradisi hajat tujuh bulan, dan tradisi numbal bumi dan lain-lain. Tradisi ini secara spiritual menguatkan semangat beragama. Namun demikian tradisi ini seiring dengan waktu harus diluruskan agar sesuai dengan aqidah dan syariat Islam.

Dengan program dakwah keluarga, diharapkan terbentuknya suatu agen yang lebih aktif menawarkan peningkatan gerakan dakwah, yang berbasis pada koordinasi antara tokoh dan stekeholder masyakakat desa setempat. Pada gilirannya terlayanihasil dakwah sebagai pengubah tatanan masyarakat desa yang lebih religius, yang lebih mensejahterakan berbagai sektor kehidupan masyarakat desa.

Fondasi budaya keagamaan dapat melanjutkan pemberdayaan. Pertama, potret tatanan sosial dan hubungan relasional antara tokoh warga setempat terjalin dengan optimal baik. Kedua, dilihat dari sarana fasilitas fisik dan sarana fasilitas sosial keagamaan di pedesaan sangat memungkinkan untuk terus diberdayakan. Kegiatan keagamaan berupa seni musik religi, kegiatan pengajian kaum ibu, dan kegiatan madrasah, fasilitasnya sudah tersedia. Juga mereka pada momentun tertentu ikut serta mengikutinya. Ke depan apabila pemberdayaan keluarga berhasil maksimal sebagai penggerak keagamaan, diharapkan terjadinya hasil dakwah yang lebih menyayomi, antisipatif, dan meningkatnya kesejahteraan.

Penelitian terkait yang pernah ada yang berhubungan dengan mitra dakwah (mad'u), antara lain mad'u dalam rangka pemberdayaan masyarakat muslim (Aziz, (2014), mad'u berbasis budaya lokal(Anif Arifani, 2014), mad'u tradisi di Batatamba (Jamalie, 2017), mad'u pada budaya Sunda (Sumpena, 2014), mad'u pada generasi muda Indonesia (Mahrudin, 2014), mad'u padaremaja terpelajar (Nurbini, 2015), mad'u mahasiswa (Komalasari, 2017), mad'u yang 
ternafikan di komunitas Samin (Rosyid, 2014), dan mad'u pada keragaman masyarakat (Nuwairah, 2017). Adapun yang berkaitan dengan falsafah dakwahnya antara lain: hubungan antara agama dan budaya (Aziza, 2017), filosofi dakwah jamaâah (Fahriansyah, 2017), internalisasi nilai keislaman melalui majelis taklim (Sarbini, 2014), seni musik religi dalam menumbuhkan kesehatan mental (Nihaya, 2014).

Penelitian ini memiliki keunikan tersendiri terkait dengan mad'u pada keluarga di pedesaan, disertai strategi pemberdayaan. Mitra dakwah yang fokus pada keluarga terutama kaum ibu dan anak-anak menjadi dinamika tersendiri dalam dakwah di pedesaan. Kaum ibu banyak terlibat dalam majlis taklim, serta anak-anak banyak terlibat dalam kegiatan tadarus al qur'an di masjid-masjid dan pendidikan agama pada madrasah. Mad'u ini menjadi elan vital dalam mendinamisasi dakwah, sehingga kegiatan keagamaan lebih berdaya dan memiliki corak tersendiri. Misalnya tampak dari pengenaan busana kerudung muslimah, pengenaan peci bagi anak-anak dan remaja muslim, ritunitas dalam taklim, dan shalat berjamaah ke mesjid. Demikian pula pada perayaan hari besar Islam, seperti Ied Fitri, Ied Adha, Maulidan, Rajaban, Muharaman, dan ramadhanan menjadi mementum yang dalam pemberdayaan kegiatan keagamaan.

Tulisan ini bertujuan untuk menggambarkan dinamika pemberdayaan keluarga dalam mendukung program dakwah di pedesaan. Perubahan pada tatanan kehidupan termasuk di pedesaan perlu adaftasi dari gerakan dakwah yang bisa mengimbangi dan mengisi perubahan menuju masyarakat yang lebih berkualitas. Keluarga merupakan komponen kelompok terkecil, paling banyak, dan paling berhubungan langsung dengan kegiatan dakwah di pedesaan. Peran serta keluarga sebagai subjek dan mitra dakwah menjadi sangat menentukan akan keberhasilan secara keseluruhan. Pada struktur keluarga yang utuh, dimana terdapat ayah, ibu dan anak merupakan komponen subjek dakwah dalam meningkatkan ketakwaan dalam berbagai sendi kehidupan, terutama sektor kepedulian sosial, pertumbuhan mualamah, tarbiyah, dan akhlak. Kegiatan dakwah yang masih terpusat dan kegiatan kaum ibu dan anak, perlu suatu sistem yang saling menyatukan. Masih banyak, kaum ibu mengantar anaknya ke sekolah/madarasah, namun para ibu tidak bersama-sama belajar agama. Fasilitas fisik, berupa bangunan mesjid, madrasah, pesantren dan panti sosial belum optimal daya gunannya dibanding nilai dari faislitas yang sudah tersedia. Peningkatan yang cepat dan teknologi informasi yang dimiliki para kelaurga terutama jejaring sosial, internet pada smartphone, seharusnya menjadi alat efektif untuk meningkatkan fungsi dakwah. Kegiatan mesjid dan fasilitas keagamaan yang ada seyogyanya terus ditingkatkan kegunaannya, bukan saja untuk ritualitas shalat dan pendidikan semata, namun harus meningkat ke arah realisasi ajaran Islam secara keseluruhan sehingga tercapai amalan Islam yang 
kaffah.

Manfaat ilmiah dari tulisan ini adalah terumuskan suatu gambaran objektif atas realitas dakwah, baik berupa mad'u, strategi, sarana dan momentum sehingga dapat menjadi inspirasi untuk perbandingan dan arah pemberdayaan. Mad'u sebagai mitra dakwahnya lebih unik pada masyarakat kaum pedesaan, bukan kaum kampus, bukan kaum profesi dan bukan kaum spesifik perkotaan.

Metode penelitian yang digunakan adalah pendekatan kualitatif dengan intervensi pemberdayaan masyarakat. Masyarakat sasaran adalah tokoh-tokoh keagamaan dan masyarakat jamaah dakwah, meliputi: Para ketua DKM, Ibu-ibu penggerak pengajian, dan para asatidz, para jamaah Ibu-ibu dan remaja serta anak-anak jamaah pengajian. Metode kegiatan dalam rangka mencapai tujuan pemberdayaan ditempuh langkah sebagai berikut: Koordinasi dengan kepala desa, ketua ormas keagamaan, ketua DKM, serta penggerak majlis ta'lim dan penggerak pengajian anak-anak dan remaja. Berikutnya membangun sinergi dengan sektor-sektor masyarakat grassroot, untuk mendengar bentuk keterlibatan yang memungkinkan mereka harapkan dan mampu ikut serta.

Fokus dakwah yang didukung dengan pemberdayaan keluarga, merupakan bagian dari dakwah yang mengubah padaperbaikan dan kebaikan. Pengembangan masyarakat adalah salah satu metode untuk memperbaiki kualitas hidup masyarakat melalui pendayagunaan sumber-sumber yang ada pada mereka pada prinsip partisipatif (Edi Suharto, 2006: 37). Pengembangan masyarakat ditujukan untuk mencapai perubahan yang lebih baik dengan objek utama masyarakat secara keseluruhan bukan hanya individu tertentu. Selain itu mengembangkan masyarakat dimaknai membuat masyarakat menjadi lebih berdaya dari kondisi kenyataan sebelumnya.

Pengembangan masyarakat Islam merupakan suatu wujud dakwah bil hal. Dakwah bil haltergolong istilah ilmu dakwah dalam mengimplikasikan hakikat dakwah melalui aksi nyata,bukan hanya melalui kata-kata atau berceramah saja. Aksi nyata tersebut ditujukan agar terwujudperubahan dari situasi problematika masyarakat Islam masa kini. Pengembangan masyarakat Islam menawarkan tindakan nyata yang dalam pemecahan masalah di berbagai bidang sosial, budaya, ekonomi, lingkungan, politikyang mengacu pada pandangan Islam (Ahmad Amirullah, 2006: 47).

Pemberdayaan dimaksudkan agar selalu meningkatnya hubungan sesama manusia untuk saling mengimani dan mengamalkan ajaran Islam. Manusia sebagai wujud makhluk sosial juga diterangkan dalam al Qur'an, surat Al Hujarat: 13, yang artinya: "Hai manusia, Sesunggubnya Kami menciptakan kamu dari seorang laki-laki dan seorang perempuan dan menjadikan kamu berbangsa - bangsa dan bersuku-suku supaya kamu saling kenal-mengenal. Sesunggubnya orang yang paling mulia diantara kamu disisi Allab ialah orang yang paling 
taqwa diantara Kamu. Sesunggubnya Allah Maha mengetahui lagi Maha Mengenal' (AlQuran dan Terjemahan, 2013).

Ayat ini memberi petunjuk bahwa manusia secara fitri merupakan makhluk sosial yang hidup bermasyarakat. Adapun pemberdayaan gerakan sosial merpakan tindakan kolektif dalam masyarakat yang terorganisir secara longgar untuk menghasilkan perubahan yang lebih baik.

Pada hakikatnya dakwah merupakan upaya untuk merubah suatu keadaan semula menjadi suatu keadaan yang lebih baik menurut tolak ukur agama Islam. Perubahan yang dimaksud adalah dengan menumbuhkan kesadaran dan kekuatan pada masyarakat sebagai mitradakwah. Dengan demikian aktivitas dakwah Islam bukan hanya sekedar suatu dialog lisan melainkan dengan perbuatan atau karya sebagai dakwah bil hal. Model pemberdayaan menuntut partisipasi aktif suatu masyarakat sebagai prasyarat utama dalam pola perubahan.

Dalam rangka meningkatkan taraf hidupdan membangun struktur sosial, haruslah berangkat dari diri masing-masing. Bukan pembangunan model top down atau langsung mengucurkan bantuan saja. Ini banyak terbukti kurang efektif dalam membangun masyarakat. Pembangunan masyarakat yang ideal menekankan keterlibatan masyarakat secara sadar dalam pembangunan (Machendrawati, 2001: 156).

Dalam pendekatan pemberdayaan masyarakat, terdapat Prinsip-prinsip Asset Based Community Development (ABCD). Pendekatan ABCD ini merupakan metode pendampingan pengembangan masyarakat yang mengupayakan manusia untuk memahami dan mengelola kekuatan, potensi ataupun asetnya untuk dimanfaatkan dengan optimal. Pendekatan ini mengarah pada pemahaman dan internalisasi aset, potensi, kekuatan, dan pendayagunaannya secara mandiri dan optimal. Pendekatan ABCDdapat diilustrasikan: "Bila kita mencari masalah, kita akan menemukan lebih banyak masalah; bila kita mencari sukses, kita akan menemukan lebih banyak sukses. Bila kita percaya pada mimpi, kita akan merengkuh keajaiban. Motto kita dalah "mencari akar penyebab sukses" bukan akar penyebab masalah" (Christopher Dureau, 2013:11).

Aset sendiri merupakan hal yang dapat digunakan atau dimanfaatkan sebagai kekayaan dalam memenuhi kebutuhan. Pendekatan berbasis aset membantu masyarakatyang dapat bekerja sama dengan fasilitator untuk melihat kenyataan mereka dan kemungkinan perubahan secara berbeda.

Menyimak pendapat Christopher Dureau (2013: 14), dan Tim KKN ABCD UIN Sunan Ampel (2015: 26), beberapa paradigma dalam pendekatan ABCD yang dapat dijadikan sebagai prinsip dalam pemberdayaan: 1) setengah 
terisi lebih berarti (half full half empty); 2) semua punya potensi untuk berkembang (nobody has nothing); 3) Semua bisa berpartisipasi (participation); 4) Semua bisa bermitra (partnership); 5) penyimpangan positif (positive deviance); 6) berawal dari masyarakat (endogenous); serta 7) menuju sumber energi (heliotropic).

Setengah terisi lebih berarti (half full half empty), ini dengan cara merubah pandangan komunitas terhadap dirinya. Tidak hanya terpaku pada kekurangan dan masalah yang dimilikinya. Tetapi masyarakat memberikan perhatian kepada apa yang dipunyai dan apa yang dapat dilakukan.

Semua punya potensi (nobody has nothing), setiap manusia terlahir dengan kelebihannya tersendiri. Semua memiliki potensi, walau hanya sekedar kemampuan untuk tersenyum dan memenuhi kebutuhan makan saja. Semua berpotensi dan semua bisa berkontribusi. Tidak ada alasan bagi setiap masyarakat untuk tidak berkontribusi nyata terhadap perubahan lebih baik. Bahkan, keterbatasan fisikpun dapat memberi kontribusi. Ada banyak kisah dan inspirasi orang-orang sukses yang justru berhasil membalikkan keterbatasan dirinya menjadi sebuah berkah, dan bahkan sebuah kekuatan.

Partisipasi (participation), merupakan suatu keterlibatan mental dan emosi seseorang pada pencapaian tujuan serta ikut tanggung jawab di dalamnya. Partisipasi menegaskan kelompok mengenal masalah mereka sendiri, mengkaji pilihan mereka, membuat keputusan, dan memecahkan masalahnya.

Kemitraan (Partnership), merupakan salah satu prinsip utama dalam pendekatanpengembanganmasyarakat berbasis aset. Partnership modal utama yang sangat dibutuhkan dalam memaksimalkan posisi dan peran masyarakat dalam pembangunan yang sedang berlangsung. Hal itu dimaksudkan sebagai bentuk pembangunan dimana yang menjadi motor dan penggerak utamanya adalah masyarakat itu sendiri (community driven development). Pembangunan yang dilakukan dalam berbagai variannya seharusnya masyarakatlah yang menjadi penggerak dan pelaku utamanya. Hal itu terjadi karena dalam diri masyarakat telah terbentuk rasa memiliki (sense of belonging) terhadap pembangunan yang terjadi di sekitarnya.

Penyimpangan Positif (Positive Deviance), menunjukkansuatu pendekatan terhadap perubahan perilaku individu dan sosial yang didasarkan pada realitas, dimana setiap masyarakat meskipun tidak banyak terdapat orang-orang yang mempraktekkan strategi atau perilaku sukses yang tidak umum. Ini memungkinkan mereka untuk mencari solusi yang lebih baik atas masalah yang dihadapi daripada rekan-rekan mereka itu.

Berawal dari masyarakat (endogenous), dimana keluarga merupakansumberdayainti dalam pembangunan yang memiliki beberapa konsep inti. Karenanya pendekatan pengembangan dan pemberdayaan komunitas 
keluarga menjadi basis kekuatan.

Menuju sumber energi (heliotropic), diantaranya memilikiharapan besar yang dimiliki oleh komunitas, proses pengembangan yang apresiatif, adanya keberpihakan anggota komunitas yang totalitas dalam mewujudkan harapan bersama.

Model ini memusatkan posisinya pada kekuatan dan keberhasilan diri dan komunitas yang dapat meningkatkan kreativitas, inspirasi, dan inovasi masyarakat untuk mendapatkan kejayaan. Kemampuan terkait potensi, kekuatan, keberhasilan, serta dibarengi dengan asset yang mereka miliki akan memberikan energi untuk mencapai keberhasilan mereka. Terjadi pengubahan cara pandang terhadap segala sesuatu menjadi lebih baik. Kita mampu dan bisa merubah kondisi hidup diri sendiri maupun orang lain.

\section{HASIL DAN PEMBAHASAN}

Data yang diperoleh berupa kegiatan sosial keagamaan yang berlangsung di Desa Mandalasari. Berikutnya disajikan data yang terkait langsung dengan kegiatan perlakuan Pengabdian kepada Masyarakat bersama dosen dan mahasiswa UIN Sunan Gunung Djati Bandung.

\section{Pertama, Kegiatan Sosial dan Keagamaan}

Dari sisi keagamaan yang menjadi masyarakat mayoritas di Desa Mandalasari yaitu Islam. Mereka memiliki beberapa amalan-amalan yang rutin dilakukan baik harian, mingguan, bulanan maupun tiap tahunan. Pendidikan keagamaan merupakan salah satu dinamika yang mendasarinya. Pendidikan mereka sadari sebagai investasi (modal) untuk bekal di masa yang akan datang. Kegiatan pendidikan formal yang diikuti terdiri dari pendidikan PAUD/TK, SD, SMP dan SMA. Untuk pendidikan nonformal terdiri dari pengajian dan pendidikan sekolah madrasah diniyah.

Posyandu berfungsi untuk melayani peningkatan kesehatan masyarakat, antara lain penimbangan balita, pelayanan KB, pemeriksaan ibu hamil, penambahan gizi posyandu diawasi oleh kader-kader kesehatan. Kader pendidikan dan pelatihan dari puskesmas tentang pelayanan kesehatan dasar.

Bangunan-bangunan yang ada khususnya bangunan sarana umum, sarana transportasi masih terbatas yang ada pun sudah banyak terjadi kerusakan. Padahal sarana ini menjadi tulang punggung ekonomi masyarakat di Desa Mandalasari. Terdapat sektor ekonomi masyarakat seperti bome industry, transportasi ojeg dan sarana lahan pertanian dan perkebunan dengan skala kecil.

Perbaikan maupun pemeliharaan agar layak digunakan untuk perkantoran 
dan balai Desa Mandalasari menjadi program prioritas desa. Sumber utama dalam pelaksanaan pembanguna masih mengharapkan dana desa (DD). Alokasi dana desa (ADD) bersumber dari dari bagi hasil pajak kabupaten dan bagi hasil rertribusi daerah. Adapun hasil dari kegiatan tersebut antara lain untuk: penyelengaraan pemerintah desa dalam melayani masyarakat desa sesuai kewenangannya; pelaksanaan pembanguna desa berupa sarana dan prasarana; pembinaan kemasyarakatan; pemberdayaan masyarakat untuk meningkatkan SDM masyarakat. Partisipasi swadaya dan gotong royong masyarakat berupa tenaga. Pada umumnya jenis sarana sosial ekonomi masyarakat berupa usaha perdagangan terutama warung kebutuhan rumah tangga sehari-hari yang berskala kecil. Disamping itu sarana ekonomi Cigunung Agung yang bermuara dan merupakan rangkaian dari DAS Cimanuk.

Pada umumnya masyarakat Desa Mandalasari sudah hampir 90\%tersambung jaringan listrik. Jaringan listrik sudah sampai ke setiap RW di Desa Mandalaasri. Hanya saja masih ada beberapa rumah tangga yang belum tersambung, karena satu kendala yakni faktor ekonomi. Mereka umumnya mengambil aliran listrik kepada tetangga terdekatnya. Jumlah rumah tangga yang memasang sambungan listrik di Desa Mandalasari pada tahun 2016 sebanyak 1.763 rumah tangga.

\section{Kegiatan Dakwah berbasis Pemberdayaan Partisipasi Keluarga}

Masyarakat sasaran yang dilibatkan secara adalah keluarga yang terdiri dari ayah, ibu dan anak. Para tokoh masyarakat penggerak seperti Dewan Kemakmuran Masjid (DKM), Ketua Yayasan Pendidikan, Kepala Desa dilibatkan untuk mensosialisasikan program. Terdapat 25 remaja dan pengasuh yang berada pada pesantren Alam Pajajaran ambil bagian. Juga terdapat empat puluh warga dari ayah, ibu dan anak remaja yang ambil bagian.

Proses kegiatan dimulai dari koordinasi dengan tokoh kunci di tingkat kecamatan dan di tingkat desa serta tokoh kampung. Di tingkat kecamatan berkoordinasi dengan kepala Kantor Urusan Agama Kecamatan Kadungora. Pada tingkat desa langsung dengan Kepala Desanya. Khusus pada tingkat kampung dengan ketua Majlis Ta'lim, DKM dan Yayasan keagamaan. Proses koordinasi menggunakan surat dan penjelasan secara lisan dalam kunjungan pertemuan dengan mereka.

Instrumen yang digunakan adalah angket DISC, fuzzle serta lembar kertas kosong. Angket DISC merupakan DISC, merupakan analisis tipe kepribadian dengan pada aspek Dominance, Influence, Steadiness, dan Conscientiousness. DISC ini merupakan identifikasi kepribadian yang paling populer untuk melihat kepribadian orang dalam konteks kelompok, termasuk dalam anggota kelompok di keluarga. Fuzzle digunakan untuk membangun kerjasama daam anggota 
keluarga, serta membangun semangat solusi dan penuntasan masalah. Kertas kosong untuk menulis harapan tawaran solusi tiap anggota dalam kelompok keluarga.

Pola kegiatan mengggunakan pendekatan family gatering. Pendekatan ini dapat membangun suasana kerjasama antar anggota kelompok anggota, juga antar tiap kelompok. Suasana menjadi cair dalam komunikasi yang ceria dan tanpa sekat umur serta status dalam keluarga ataupun status dalam masyarakat.

Tahapan kegiatan dimulai dari ice breaking, perkenalan dan keceriaan. Berikutnya ditawarkan rangkaian game kebersamaan keluarga antara ayah, ibu dan anak, atau antara anak santri dengan pengasuhnya. Tawarannya dengan mengisi angket secara individu, atau menyusun fuzzle bersama-sama satu anggota keluarga, dan/atau mengisi lembar harapan tiap anggota kelurga pada kertas kosong.

Hasil dari kegiatan menggunakan instrumen DISC, terdapat generalisasi bahwa gejala konflik dalam anggota keluarga sering kali dipicu oleh pembedaan jenis kepribadian yang mencolok. Keadaan kontras ini, menimbulkan suasana harmonisasi dalam keluarga menjadi terganggu bahkan kacau yang berujung fatal pada benih-benih perpecahan. Pengenalan dan identifikasi jenis kepribadian tiap anggota keluarga dapat memudahkan penataan dalam membangun keluarga yang religius Islamis.

Penggunaan fuzzle dapat memacu semangat dan kesadaran bahwa masalah dalam keluarga menarik untuk dipecahkan secara bersama-sama. Tiap angggota mengambil peran secara proaktif. Tidak saling mengandalkan, bahkan berebut untuk menjadi pemberi solusi. Yang menarik dalam game ini tidak ada suara dan tidak ada instruksi dan ayah maupun ibu. Semua berjalan dengan ceria dan tuntas. Tentu tiap kelompok berbeda waktu dalam menyelesaikan tugas dalam game ini.

Dalam pengisian kertas kosong tiap anggota membuat tanggapan filosofis atas permainan yang mereka lakukan. Demikian juga kertas kosong ini dapat mereka gunakan untuk menulis harapan-harapan peran proaktif adalam kelurga. Keadaan menjadi meringankan tugas-tugas ibu di rumah serta tugas-tugas ayah dipekerjaan.

Pada implementasi dakwah dalam dukungan keluarga baik keluarga dalam kontek internal maupun eksternal, dapat dirumuskan di antara mereka. Kegiatan keagamaan, misalnya shalat wajib lima waktu menarik dibahas mereka. Dalam shalat berjamaah menjadi terbagi tanpa suara, siapa yang harus menyiapkan shaf, busana shalat, menjadi mua'adzin, imam, ataupun membereskan setelahnya. Demikian juga dalam kegiatan pertemuan kegiatan keagamaan misalnya pengajian umum dan peringatan hari besar Islam dapat mereka berbagi tugas secara proaktif. Ayah, ibu dan anak secara aktif menjadi bagian dari sukses acara. 
Keluarga dalam bahasa arab disebut ahlun, disamping kata ahlun kata yang juga bisa memiliki pengertian keluarga adalah ali dan asyir. Kata ahlun berasal dari kata ahila yang berarti senang, suka, atau ramah. Menurut pendapat lain, kata ahlun berasal dari kata ahala yang berarti menikah. Secara lebih luas, ahlun adalah sekelompok orang yang disatukan oleh hubunganhubungan tertentu, seperti hubungan darah (keluarga), agama, pekerjaan, rumah atau negara. Kata ahlun memiliki tiga pengertian (Waryono Abdul Ghafur, 2006: 320), yaitu: pertama, menunjuk pada manusia yang memiliki pertalian darah atau perkawinan, seperti ungkapan ablu al-bait dalam bahasa Indonesia disebut keluarga; kedua, menunjuk pada suatu penduduk yang mempunyai wilayah-geografis atau tempat tinggal, seperti ucapan ablu al-quran, abli yatsrib, ablu al-balad dan lain-lain dalam bahasa sehari-hari disebut warga atau penduduk; ketiga menunjukkan pada status manusia secara teologis seperti ablu al-diৃikr, ablu al-kitab, ablu al-nar, ablu al-jannah dan sebagainya; keempat, meskipun tampak ada perbedaan, namun ketiganya sebernanya terkait, yakni ablun yang berarti orang memiliki hubungan dekat, baik karena perkawinan, satu kampung, kampus, negara, atau satu agama. Terjalinnya hubungan kedekatan itu menjadikan pergaulan diantara mereka hidup dengan suka cita, senang, damai dan sejahtera.

Dalam kehidupan seseorang tidak akan lepas dari keluarga.Dari sinilah permulaan kehidupan sosial seseorang berlangsung. Keluarga merupakan unit terkecil dari masyarakat sekaligus sebagai kelompok kecil dalam masyarakat. Menurut Abu Ahmadi (2001: 87), keluarga terbagi menjadi dua: pertamakeluarga kecil (nuclear family)yang terdiri dari suami, isteri, dan anak-anak mereka, yang kadang-kadang disebut juga sebagai conjugal family; kedua keluarga besar (extended family), didasarkan pada hubungan darah dari sejumlah besar orang, meliputi orang tua, anak, kakek-nenek, paman, bibi, kemenekan, dan seterusnya yang sering disebut sebagai keluarga berdasarkan pertalian darah (conguine family).

Dalam pandangan Mufidah (2008: 41), ada tiga jenis hubungan dalam keluarga: pertama, kerabat dekat (conventional kin)terdiri dari individu yang terkait dalam keluarga melalui hubungan darah, adopsi, dan atau pernikahan, seperti suami-istri, orang tua, anak, dan antar saudara (siblings); kedua, kerabat jauh (discretionari kin), yaitu terdiri dari individu yang terikat dalam keluarga melalui hubungan darah, adopsi atau pernikahan, tetapi ikatan keluarganya lebih lemah dari pada kerabat dekat; ketiga, orang yang dianggap keluarga (fictive kin), karena adanya hubungan yang khusus, misalnya hubungan antar seseorang yang akrab.

Islam menganggap keluarga merupakan milleniu pertama dan utama bagi setiap individu dimanapun berinteraksi. Individu memerlukan keluarga bukan 
hanya pada tingkat awal dalam kehidupannya semata, tetapi dalam sepanjang hidupnya, dari kanak-kanak sampai tuanya untuk mendapatkan ketenangan dan kebahagiaan.

Dalam suatu keluarga dituntut untuk melakukan segala sesuatu yang menjadi kewajibannya, terutama dengan anggota keluarga dan lingkungan sosialnya. Tatkala menjalankannya, maka keluarga itu telah menjalankan fungsinya. Mufidah (2008: 42), diantara fungsi-fungsi dari intitusi keluarga dalam konteks kehidupan sosial adalah: fungsi biologis, fungsi edukatif, fungsi religius, fungsi protektif, fungsi sosial budaya, fungsi ekonomi, fungsi reproduksi, dan fungsi rekreatif.

Keluarga merupakan kelompok kecil yang tinggal bersama dalam sebuah lingkungan dalam keadaan sosial masyarakat yang dibangun atas bersatunya kedua individu dalam ikatan syariat Islam. Kehidupan yang dijalani keluarga dinaungi oleh aturan syariat serta tuntunan agama agar senantiasa berada pada koridorIslam sebagaimana yang telah dicontohkan Rasulullah SAW.

Dilihat dari fungsinya, keluarga merupakan kelompok sosial terkecil yang menjalani kehidupan bersama-sama dan terlibat dalam suatu kerjasama. Terdapat beberapa fungsi lainnya dalam keluarga antara lain: fungsi keagamaan, fungsi sosial budaya, fungsi cinta kasih, fungsi melindungi, fungsi reproduksi, fungsi sosialisasi dan pendidikan, fungsi ekonomi,dan fungsi pembinaan lingkungan (Bambang Ismaya, 2015: 150-152).

Menyoroti fungsi keagamaan, keluarga sebagai satu kesatuan masyarakat terkecil yang memiliki tanggung jawab akhlak untuk membimbing anggotanya menjadi manusia yang berakhlak mulia, beriman dan bertakwa. Dalam fungsi sosial budaya, keluarga merupakan awal dari terciptanya masyarakat yang berbudaya, saling menghormati dan rukun antar tetangga. Dalam fungsi cinta kasih, anak-anak pertama kali belajar untuk memiliki rasa cinta kasih terhadap lingkungannya melalui keluarganya. Anak yang dibesarkan dalam suasana cinta dan kasih sayang yang berlimpah maka akan tercermin pula sikap tersebut dalam kehidupan bermasyarakat.

Kedudukan seorang ibu dalam keluarga merupakan sosok yang berperan penting selain dari seorang ayah. Peranannya menjadi seseorang istimewa sebagai kodratinya menjadi ibu rumah tangga yang mengemban bagian tugas penting didalamnya. Depag RI (2013),peran wanita dan laki dalam keluarga sebagai Allah berfirman dalam Al Quran Surat An-Nisa' ayat 34 yang artinya: 'Laki-laki adalah pelindung bagi perempuan (istri). karena Allabtelab melebibkan sebagian mereka terhadap sebagian yang lain dan sebab mereka telah memberikan nafkah dengan hartanya. Maka mereka perempuan-perempuan yang saleh adalah mereka yang taat kepada Allah dan menjaga diri ketika suaminya tidak ada karena Allab menjaga mereka. Perempuanperempuan yang kamu khawatirkan akan nusyuz hendaklah kamu beri nasehat kepada 
mereka, tinggikanlah mereka di tempat tidur dan jika perlu pukullah mereka. Tetapi jika mereka menantimu, maka janganlah mencari-cari alasan untuk menyusabkannya. Sunggub Allah maha tinggi dan maha besar. Ayat tersebut menjelaskan tentang organisasi terkecil yaitu keluarga (rumah tangga). Dijelaskan juga keistimewaan peraturannya untuk mencegah terjadinya keluarga yang tidak harmonis. Pada penggalan berikutnya dibahas kriteria wanita salihah yang pada intinyamereka adalah wanita-wanita yang patuh terhadap para suamimereka.

Selanjutnya secara lebih lebih jelas Quraisy Shihab dalam tafsirnya menyatakan bahwa wajib patuh kepada suami dalam segala hal yang tidak bertentangan dengan ajaran agama Islam. Quraisy Shihab (2002: 516), arti wanita taat kepada suaminya adalah sebagaimana dikemukakan dalam beberapa Hadis sebagai berikut: sebaik-baik wanita adalah seorang istri yang apabila kamu melihat kepadanya, membuatmu gembira; dan apabila kamu memerintahkannya, maka ia mentaatimu; dan apabila kamu pergi meninggalkan dia, maka ia memelihara kehormatan dirinya dan hartamu.

Kehidupan sosial keagamaan merupakan perilaku yang berhubungan dengan tuntutan dan kebutuhan masyarakat lainya. Perilaku sosial keagamaan termasuk mendidik anak sejak kecil agar terbiasa menjalankan perilaku sosial, kesadaran iman yang mendalam agar ditengah-tengah masyarakat nanti ia mampu bergaul dan berperilaku sosial yang baik, memiliki keseimbangan akal yang matang dan tindakan yang bijaksana (Abdul Hamid, 2009: 26). Adapun bentuk-bentuk sosial keagamaan yang menjadi perhatian antara lain aktif dalam organisasi keagamaan, berakhlak mulia, serta menghargai terhadap sesama dan tidak (Soekanto, 2004: 113).

Seorang anak yang memiliki perilaku sosial yang baik diantaranya ditandai dengan aktifitas dalam organisasi keagamaan dimana ia tinggal. Suatu organisasi itu sangat penting bagi pembentukan sosial seseorang. Dengan berorganisasi seseorang dapat berlatih bagaimana cara berinteraksi dengan orang lain dengan cara yang baik, bersosial, dan berlatih untuk dapat menghargai sesama. Seorang yang berakhlak baik, suka memberi, menolong mudah memafkan kesalahan orang lain, bisa menghargai sesama, menunjukkan bahwa seorang tersebut memiliki rasa sosial keagamaan yang tinggi.

Soekanto (2004:117), .terdapat tiga faktor sosial keagamaan anak dalam keluarga, yakni faktor dari dalam (internal), faktor dari luar (eksternal), serta faktor kekuatan dasar dari lingkungan. Faktor internal adalah faktor yang berasal dari dalam diri seseorang. Faktor-aktor tersebut dapat berupa insting, motif dari dalam dirinya, sikap serta nafsu. Faktor internal yang bermacammacam berada dalam diri seseorang akan menimbulkan bentuk perilaku sosial keagaman yang bermacam-macam. Faktor eksternal adalah faktor yang berasal dari luar diri seseorang atau individu. Faktor yang timbur dari lingkungan 
keluarga, sekolah dan masyarakat. Faktor eksternal ini dapat berupa pengaruh lingkungan sekitar tempat dimana individu tersebut hidup dan ditambah dengan adanya hukuman dan hadiah yang ada dalam komunitas tersebut. Faktor lingkungan berperan penting bagi kehidupan sosial agama anak, baik itu lingkungan keluarga maupun lingkungan pendidikan.

Kondisi masyarakat, baik maupun buruk, tidak akan dirubah oleh Allah SWT hingga mereka terlebih dulu melakukan perubahan terhadap apa yang terdapat pada diri mereka berupa pemahaman, pemikiran dan asumsi-asumsi. Tanpa melakukan hal tersebut, maka harapan untuk mendapatkan perubahan kondisi dari Allah adalah menyalahi teks ayat sekaligus mengingkari tugas kekhalifahan manusia (Muhammad Munir, dan Wahyu Ilaihi, 2006: 256).

Kondisi sosial masyarakat pada dasarnya diskonstruksi oleh manusia sendiri, bukan oleh Tuhan. Oleh sebab itu pengembangan dan perubahan akan terjadi jika manusia itu sendiri yang akan melakukakan perubahan, bukan oleh Tuhan, meskipun tuhan sendiri punya kuasa untuk melakukan itu. Perubahan dicapai dengan mempersiapkan sumber daya manusia yang handal yang akan menjadi agen perubahan (agent of change). Tentunya seorang agen perubahan mampu merubah beberapa aspek kehidupan masyarakat yang sesuai dengan syariat Islam seperti aspek muamalat, ekonomi, sosial kemasyarakatan, politik dan lain sebagainya.

\section{Peran dan Kewajiban sebagai Anggota Keluarga}

Pola keluarga dalam Islam, memberikan penjelasan tentang kewajiban masingmasing suami-istri tentang tanggung jawab. Masing-masing suami istri kepada pasanganya memiliki rasa tanggung jawab bersama dalam mengelolah bangunan keluarga serta menyburkan susasana kebahagiaan, kemantapan, bekerja sama dalam bingkai kasih sayang.

Kewajiban suami terhadap istri, suami dengan mengemban kewajiban memperhatikan anggota keluarga dengan melaksanakan hak-haknya. Pertama, kewajiban memperhatikan istri dalam hal pelaksanaan terhadap kewajibankewajiban keagamaan, mengajarkan hukum-hukum agama, mengarahkan dan mendidik perilakunya serta memperbaiki ketika diperlukan. Kedua, kewajiban menjadi pendamping yang dengan perilaku terhormat dan menolak segala kemudoratan sebagai perwujudkan perintah Allah SWT. Ketiga, kewajiban memeberikan nafkah kepada istri sesuai dengan batasan-batasan kemampuan dan wajar, tidak boros atau kikir. Allah telah menganugerahkan kemampuan kepada laki-laki untuk bekerja dan berusaha menghadapi rintangan hidup yang berat (Karzoun, 2004:204-209).

Kewajiban istri terhadapsuamimemiliki tanggung jawab juga dalam keluarga. Ia harus mengurus segala hal yang ada dalam keluarga. Hal itu 
merupakan perwujudan dari kewajiban saling membantu dan bekerja sama antara suami dan istri, sekaligus membangun keharmonisana abadi. Kewajiban tersebut antara lain: pertama, seorang istri wajib taat kepada suami, sebagai pengakuan atas kemuliaan dan kepemimpinanya. Dalam al-qur'an dijelaskan karekteristik perempuan sholihah dalam sikap dan perilaku dalam lingkungan keluarga. Salah satu karakteristiknya adalah kepatuhan yang berdasarkan ketulusan, kesenangan, dan kecintaan, bukan berdasarkan paksaan dan intimidasi. Kedua, istri wajib memelihara jiwa dan harta kelurga. Hal ini dapat dilakukan dengan cara menggunakan harta seperlunyasaja, menjahui halhal yang mengarah pada pemborosan. Ketiga, seorang istri wajib mengurus pekerjaan dalam rumah tangga. Karena seorang istri adalah penanggung jawab rumah dan keluarga sejauh kemampuanya (Agus Riyadi, 2003: 7).

Selain memiliki hak atas anak-anaknya, orang tua juga memiliki kewajiban terhadap mereka. Al-Qur'an dan sunnah banyak menyebut hal ini, yang akan mencerahkan pikiran dan nurani. Anak adalah karunia terbesar dari Allah SWT yang mengharuskan bersyukur kepadanya. Karunia apapun yang diberikan Allah SWT mesti diperlakukan secara adil.

Adapun kewajiban-kewajiban orang tua terhadap anak, antara lain:

Pertama, memberi rasa aman kepada anak, membentuk intelektualitas serta memenuhi kebutuhan fisik mereka sehinggaterjadi perkembangan berkesinambungan. Kedua, membekali anak dengan pendidikan Islam memenuhi kebutuhan kesehatan, keamanan, dan membesarkan anak. Semua tanggung jawab atas kebutuhan makan, obat-obatan, sandang, papan, termasuk melindungi martabat dan kehormatan anak, terletak pada sang ayah (Najafi \& Khalfan, 2006: 41-43). Ketiga, kewajiban adil terhadap anak, termasuk faktor penting untuk kematangan jiwa. Hal itu akan memberikan kesenangan pada diri meraka dan membuat hati mereka terasa aman-tentram. Oleh karena itu Islam sangat menekankan keadilan. Sesungguhnya perlakuan yang baik dan adil di hadapan anak-anak merupakan faktor adanya kebaktian anak-anak (Abdurrahmman Al-Akk, 2006: 195).

Kegiatan berdakwah dikalangan keluarga harus terus digelorakan agar dakwah tidak pernah padam. Kegiatan berdakwah merupakan kewajiban sebagai hamba yang diutus ke muka bumi untuk menjalankan tugas dan fungsi sebagai hamba-Nya. Kewajiban berdakwah pada dasarnya merupakan amanah yang harus dijalankan oleh setiap individu dalam menjalani kehidupan. Hal ini sebagaimana Q.S Yunus ayat 25: "Allah menyeru (manusia) ke darussalam (surga), dan menunjuki orang yang dikehendaki-Nya kepada jalan yang Lurus (Islam)". Kemudian dalam Q.S Al Baqarah ayat 168 dan 221 menerangkan bahwa: "Hai sekalian manusia, makanlah yang halal lagi baik dari apa yang terdapat di burni, dan janganlah kamu mengikuti langkah-langkah syaitan; karena 
sesungguhnya syaitan itu adalah musuh yang nyata bagimu." Q.S An-Nahl ayat 125:"Serulah (manusia) kepada jalan Tuhan-mu dengan hikmah dan pelajaran yang baik dan bantahlah mereka dengan cara yang baik. Sesungguhnya Tuhanmu Dialah yang lebih mengetahui tentang siapa yang tersesat dari jalan-Nya dan Dialah yang lebih mengetahui orang-orang yang mendapat petunjuk".

Makna dakwah merupakan ajakan atau seruan kepada jalan kebenaran melalui sebuah pesan yang disampaikan. Makna dari istilah dakwah itu sendiri begitu luas dan tidak bisa ditafsirkan dalam kontek tertentu, akan tetapi bisa ditafsirkan pada berbagai istilah yang terkait pada kegiatan berdakwah.

Pada dasarnya, sistem dakwah terbentuk dari beberapa sub sistem yang merupakankomponen yang lebih kecil dan merupakan bagian dari sistem dakwah. Beberapa sub sistem yang merupakan komponen dari dakwah tersebut tidak lain adalah unsur-unsur dakwah itu sendiri, yaitu da'i (subjek dakwah), mad'u (mitra dakwah), maddah (materi dakwah), wasilah (media dakwah), thariqah (metode dakwah), dan atsar (efek dakwah). Keseluruhan dari subsistemsubsistem dakwah ini merupakan satu kesatuan yang terkait satu sama lainnya. Jika satu sub sistem saja terlepas atau diabaikan dan keseluruhan dakwah maka targetyang merupakan cita-cita dakwah terganggu (Moh. Ali Aziz, 2004: 73). Setiap sub sistem dalam kegiatan dakwah tidak dapat dipisah, karena merupakan bagian yang berperan penting bagi keberhasilan proses dakwah itu sendiri.

Berdakwah tentu saja diperlukan keinginan atau motivasi yang kuat sebagai tujuan akhir dari proses penyampaian pesan dari da'i kepada mad'u. Motivasi atau tujuan tersebut harus senantiasa disampaikan pada setiap aktivitas dakwah. Tanpa adanya tujuan, suatu aktivitas yang dikerjakan akan menjadi hampa tidak bermakna(An-Nabiry, 2008: 58).

Metode dakwah adalah cara yg teratur dan baik untuk mencapai maksud; atau cara kerja yang tersistematis untuk memudahkan pelaksanaan suatu kegiatan guna mencapai tujuan yang diteritukan. Metode dakwah (ushlub al-sa'wah) merupakan suatu cara dalam melaksanakan dakwah, menghilangkan rintangan atau kendala-kendala dakwahagar mencapai tujuan dakwah secara maksimal. Ini sebagaimana yang tertuang dalam al-Qur'an surat Ibrahim ayat 4: "Dan Kami tidak mengutus seorang rasul pun melainkan dengan bahasa kaumnya supaya dia dapat memberi penjelasan dengan terang kepada mereka." Membahas metode dakwah selaras apabila merujuk pada Q.S an-Nahl ayat 125:"Serulah (manusia) kepada jalan Tuhan-mu dengan hikmah dan pelajaran yang baik dan bantahlah mereka dengan cara yang baik. Sesungguhnya Tuhanmu Dialah yang lebih mengetahui tentang siapa yang tersesat dari jalan-Nya dan Dialah yang lebih mengetahui orang-orang yang mendapat petunjuk".

Ayat ini dipahami oleh ulama memuat tiga macam metode dakwah yang harus disesuaikan dengan sasaran dakwah. Terhadap cendekiawan yang 
memiliki pengetahuan tinggi diperintahkan menyampaikan dakwah dengan hikmah yakni berdialog dengan bijak sesuai dengan tingkat kepandaiannya. Terhadap kaum awam, diperintahkan untuk menerapkan yakni memberi nasihat serta perumpamaan yang menyentuh jiwa sesuai dengan taraf pengetahuannya yang sederhana. Sedangkan terhadap ahli kitab dan penganut agama-agama lain yang diperintahkan adalah jadal (perdebatan) dengan cara yang terbaik yaitu dengan logika dan retorika ulung.

Dalam konteks pemberdayaan, Islamadalahagamarahmatanlilalamin. Islammerupakanagamayang saratakanmanfaatdan maslahat baik bagi individu maupun komunitas sosial.Islammerupakan agamayang yang senantiasamengajarkan untuk memberikan manfaat dan maslahat kepadasesama makhluk manusiamaupun makhluk lainnya.Islam mengajarkan kepada umatnya untuk saling tolong menolong. Segala bentuk perbedaan yang mewarnai kehidupan manusia merupakan salah satu isyarat kepada umat manusia agar saling membantu satu sama lain.SebagaimanafirmanAllah dalam surah AlMaidah ayat 2: "Dan tolong-menolonglahkamudalam(mengerjakan). kebajikan dan takwa, dan jangan tolong-menolongdalam berbuatdosa dan pelanggaran.”(QS. Al-Maidah: 2).Adanya sikap tolong menolong merupakan sikap yang mampu mengubah kehidupan sosial masyarakat. Sikap tolong menolong akan menimbulkan sikap yang lain seperti halnya gotong royong dalam kehidupan masyarakat contohnya seperti: membangun rumah, kerjabakti di jalan, pembangunan posiandu serta peningkatan kesejateraan terhadap masayarakat yang lainnya.

Pemberdayaan secara substansial merupakan proses memutus (break down)dari hubungan antara subjek dan objek. Proses ini mementingkan pengakuan subjek pada kemampuan atau daya yang dimiliki objek. Secara garis besar proses ini melihat pentingnya mengalirkan daya dari subjek ke objek. Hasil akhir dari pemberdayaan ini adalah beralihnya fungsi individu yang semula menjadi objek menjadi subjek baru,sehingga relasi sosial nantinya akan dicirikan dengan relasi sosial antar subjek dengan subjek lain(Aziz, 2004: 169).

Proses pemberdayaan mengandung dua kecenderungan (Adi Fahrudin: 2014:48). Pertama, proses pemberdayaan dengan kecenderungan primer yang menekankan pada proses pemberian kekuasaan, kekuatan atau kemampuan kepada masyarakat agar individu yang bersangkutan menjadi lebih berdaya. Proses ini dapat dilengkapi dengan upaya membangun aset material guna mendukung pembangunan kemandirian mereka melalui organisasi. Kedua, proses pemberdayaan dengan kecenderungan sekunder menekankan pada proses menstimulasi, mendorong atau memotivasi agar individu mempunyai kemampuan atau keberdayaan untuk menentukan apa yang menjadi pilihan 
hidupnya melalui proses dialog.

\section{PENUTUP}

Demikian kajian mengenai dakwah dalam konteks pemberdayaan partsipasi keluarga di pedesaan yang dapat diemban keluarga. Model pelatihan ini dapat dilaksanakan secara dinamis dan kondisional. Terdapat penelitian lebih lanjut yang dapat dikembangkan antara lain penelitian partisipasi dakwah pedesaan pada masyarakat yang lebih spesifik seperti masyarakat petani, home industry, lansia, dan masyakat berkebutuhan khusus.

\section{DAFTAR PUSTAKA}

Abdurrahmman, K.B..(2006). Cara Islam Mendidik Anak. Yogyakarta: Ad-Dawa'

Ghafur, W.A. (2006). Hidup Bersama al-Qur'an Jawaban al-Qur'an Terhadap Problematika Sosial. Yogyakarta: Pustaka Rihlah.

Fahrudin, A. (2014). Modul Participatory Action Research (PAR). Surabaya: LPPM UINSA.

Ahmad, A. (2006). Dakwah Islam dan Perubahan Sosial. PLP2M, Jakarta

Arifani, M.A. (2014). Model Pengembangan Dakwah Berbasis Budaya Lokal. Ilmu Dakwah: Academic Journal for Homiletic Studies, 5(15), 849-978.

An-Nabiry, F. B. (2008). Meniti Manhaj Dakwah Bekal Perjuangan Para Da'i. Jakarta: Amzah

Aziz, M. A. (2004). Ilmu Dakwah. Jakarta: Kencana

Aziz, R. (2014). Dakwah Dalam Paradigma Pemberdayaan Masyarakat Muslim.Ilmu Dakwah: Academic Journal for Homiletic Studies, 5(16), 117-144.

Aziza, A. (2017). Profesi Penyuluh Agama diantara Dinamika Realita Sosial Keagamaan. Alhadharah: Jurnal Ilmu Dakwah, 13(26), 37-44.

Dureau, C. (2013). Pembaru dan Kekuatan Lokal untuk Pembangunan. Development and Civil Society Strengthening Scheme (ACCESS) Phase II.

Fahriansyah. (2017). Filosofi Dakwah Jama'ah. Alhadharah: Jurnal Ilmu Dakwah, $15(29)$,

Ismaya, B. ( 2015). Bimbingan \& Konseling studi, Karier, dan Keluarga. Bandung: PT Refika. Aditama

Jamalie, Z. ( 2017). Dakwah Kultural: Dialektika Islam dan Budaya dalam Tradisi Batatamba. Alhadharah: Jurnal Ilmu Dakwah. 11(21), 51-65. 
Karzoun, A. H.( 2004). Bahagia Setelah Menikah. Yogyakarta: Diva Press.

Komalasari, S.(2017). Motif Berprestasi Mahasiswa Berdakwah. Alhadharah: Jurnal Ilmu Dakwah. 14(28), 1-11.

Mahendrawati, N. (2001). Pengembangan Masyarakat Islam. Bandung: PT Remaja Rosda Karya

Mahrudin. (2014). Kontribusi Falsafah Pobinci-Binciki Kuli Masyarakat Islam Buton Bagi Dakwah Islam Untuk Membangun Karakter Generasi Muda Indonesia. Jurnal Dakwah.15(2), 335-355.

Mufidah. (2008). Psikologi Keluarga Islam. Malang: UIN Malang Press

Munir, M. \& Ilaihi, W.( 2006). Manajemen Dakwah. Jakarta: Kencana

Najafi, I.H. \& Khalfan, M.A. (2006). Pendidikan dan Psikologi Anak. Jakarta: Cahaya.

Nihaya, U. (2014). Konsep Seni Qasidah Burdah Imam Al Bushiri Sebagai Alternatif Menumbuhkan Kesehatan Mental.Ilmu Dakwah: Dakwah dan Pemberdayaan Masyarakat, 34(2), 295-308.

Nurbini. (2015). Bahasa Dakwah Untuk Kalangan Remaja Terpelajar. Jurnal Dakwah. 12(1), 117-135.

Nuwairah, N. (2017). Dakwah di Tengah Keragaman Masyarakat: Hakikat dan Strategi. Alhadharah: Jurnal Ilmu Dakwah. 13(25), 15-26.

Riyadi, A. (2003). Bimbingan Konseling Perkawinan dalam Membentuk Keluarga Sakinah. Yogyakarta: Ombak

Rosyid, M. (2014). Objek dakwah Yang Ternafikan: Studi Kasus Pada Komunitas Samin. Jurnal Dakwah. 15(2), 235-263.

Sarbini, A. (2014). Internalisasi Nilai Keislaman Melalui Majelis Taklim. Ilmu Dakwah: Academic Journal for Homiletic Studies. 5(16), 53-69.

Shihab, Q. (2002). Membumikan Al-Quran, cet. XXII. Bandung: Mizan

Soekanto, S. (2004). Sosiologi Keluarga Tentang Ikhwal Keluarga Remaja dan Anak. Jakarta: Rineka Cipta

Suharto, E. (2010). Membangun Masyarakat Memberdayakan Masyarakat. Bandung: Refika Aditama

Sumpena, D. (2014). Islam dan Budaya Lokal: Kajian terhadap Interelasi Islam dan Budaya Sunda. Ilmu Dakwah: Academic Journal for Homiletic Studies. 6( 1), 101-120. 
S. Miharja, Syamsudin 